\title{
Oxybutynin as an alternative treatment for hyperhidrosis*
}

\author{
Sergio Delort ${ }^{1}$ \\ Marcos Antônio Corrêa ${ }^{3}$ \\ DOI: http://dx.doi.org/10.1590/abd1806-4841.201755126
}

Evaldo Marchi

\begin{abstract}
Hyperhidrosis is the excessive production of sweating, which can be primary and focal or secondary to various pathologies. The exact cause of primary focal hyperhidrosis is still unknown, although a genetic basis is recognized, and its prevalence varies from $1 \%$ to $2.8 \%$. The most affected sites are the armpits, palms, soles and face. It causes much discomfort, affects the quality of life, and is estimated to be undervalued by health professionals. Many treatment options are proposed, both clinical and surgical. The aim of this review is to focus on the treatment of hyperhidrosis with oxybutynin, an anticholinergic drug originally used to control overactive bladder.
\end{abstract}

Keywords: Cholinergic antagonists; Hyperhidrosis; Therapeutics

\section{INTRODUCTION}

Hyperhidrosis is characterized by an overproduction of sweat, beyond what is necessary for thermal control. It is clinically divided in primary, of unknown cause, and secondary to several diseases, such as endocrine disorders, drugs, tumors and abnormalities of the nervous system. Primary hyperhidrosis is more common and is characterized by being symmetrical, most frequently reaching specified regions (mainly the axillary and palmar-plantar region), with frequency of at least once a week, starting before 25 years of age, ceasing during sleep and having a familiar predisposition. ${ }^{1}$

The cause of primary hyperhidrosis is not fully known, and it has been attributed to increased cholinergic stimulation, since studies show no hypertrophy or hyperplasia of the sweat glands. ${ }^{2} \mathrm{~A}$ family history has been reported, supporting a genetic basis. ${ }^{3}$

A large study with questionnaires applied to American families showed an incidence of hyperhidrosis in 6,800 individuals in a universe of 150,000 people surveyed, projecting a number of 7.8 million Americans with hyperhidrosis. Of these, 4 million present with axillary hyperhidrosis (1.4\% of the American population). There was equivalence in the involvement of men and women. ${ }^{4}$

In respect of quality of life, several studies show worsening in patients with primary hyperhidrosis. Studies report that the effects of hyperhidrosis are compared with more serious diseases such as severe psoriasis, renal failure at advanced stages, rheumatoid arthritis and multiple sclerosis. ${ }^{5}$ Patients refer difficulties at work and decreased productivity, wasted time trying to control their disease, problems in relationships with friends and sexual relations, social phobia and difficulty with recreational activities, sports and manual and writing skills. ${ }^{6}$ In addition to the psychosocial aspect, focal hyperhidrosis can increase the incidence of other skin diseases such as infections caused by fungi and bacteria, increased viral warts, eczematous lesions and bromhidrosis. ${ }^{7}$

The diagnosis is eminently clinical and the first step is to differentiate between primary and secondary types, through anamnesis and clinical characteristics. Although we can try to quantify the perspiration through the iodine starch test, which consists in the application of $1 \%$ to $5 \%$ iodine solution sprinkled with starch to the affected areas. This solution, in the presence of perspiration, forms a characteristic purplish sediment. ${ }^{1}$ Another objective method to quantify the sweating is the use of a non-invasive portable device with moisture sensors able to quantify the loss of transdermal water. $^{8}$ In addition, subjectively tests can be applied in the form of questionnaires, such as the severity scale of the hyperhidrosis-HDSS disease and the clinical protocol on the quality of life. ${ }^{9,10}$

Treatment of hyperhidrosis is divided in clinical or surgical. Topical treatments (aluminum chloride and other metal salts) and glycopyrrolate are available. ${ }^{11}$ Orally, there are anticholinergic agents like glycopyrrolate and methantheline that compete with muscarinic receptors. Of note, oxybutynin is one of the most used agents in clinical practice. Beta-blockers are also used to improve symptoms of social phobia and anxiety. Other described drugs are alpha adrenergic agonists such as clonidine, benzodiazepines, calcium channel blockers, propantheline, and gabapentin - all with few studies. ${ }^{12,13}$

The botulinum toxin blocks the binding of acetylcholine and numerous other neurotransmitters in the presynaptic vesicles by temporary chemical denervation. ${ }^{3}$ Its use can be conveyed both by iontophoresis or phonophoresis in an injectable manner. ${ }^{3,14}$

Apparatus for reducing hyperhidrosis include micronee-

Received on 13.09.2015

Approved by the Advisory Board and accepted for publication on 28.02.2016

* Study conducted at the Faculdade de Medicina de Jundiaí (FMJ) - Jundiaí (SP), Brazil.

Financial support: none.

Conflict of interest: none.

Graduate program of the Faculdade de Medicina de Jundiaí (FMJ) - Jundiaí (SP), Brazil.

Departament of Thoracic Surgery of the Faculdade de Medicina de Jundiaí (FMJ) - Jundiaí (SP), Brazil.

Departament of Drugs and Medicines of the Universidade Estadual Paulista "Júlio de Mesquita Filho" (Unesp) - Botucatu (SP), Brazil.

(C2017 by Anais Brasileiros de Dermatologia

An Bras Dermatol. 2017;92(2):217-20. 
dling with fractionated radiofrequency, microwave, long-pulsed diode laser and $1064 \mathrm{~nm}$ Nd-YAG laser, and VASER ultrasound. ${ }^{15}$

Regarding surgical treatment, there are local surgeries to attempt to remove glands such as skin resection of the axillary region, removal of subcutaneous tissue without excision of the skin and liposuction with curettage. ${ }^{16}$ Another effective form of surgical treatment is video assisted thoracoscopy sympathetic blockade (sympathectomy), which can be accomplished by excision, ablation or clipping of the sympathetic chain. ${ }^{17}$

The present study aims at conducting a literature review on the use of the anticholinergic agent oxybutynin for the treatment of hyperhidrosis.

\section{METHOD}

A literature search was performed in the United States National Library of Medicine databases (PubMed). The keywords used for the search were hyperhidrosis and oxybutynin. The research involved all scientific articles published until August 2015.

\section{RESULTS}

The first report using oxybutynin for hyperhidrosis occurred in $1988 .{ }^{18}$ Later reports on the use of the drug in diabetic patients with gustatory sweating were published in an anecdotal manner. ${ }^{19,20}$ In 2003, Shimizu et al., investigating the effectiveness of iontophoresis, indicated the concomitant use of oxybutynin $4 \mathrm{mg}$ per day with good results. ${ }^{21}$ Reports of isolated cases have been sporadically published..$^{22-25}$ The first trial with a larger number of patients was conducted from June 2004 to May 2005. During four weeks, 14 patients with generalized hyperhidrosis were treated with an initial prescription of $2.5 \mathrm{mg}$ of oxybutynin every 8 hours. Of these, eight patients had good results, three had to increase the dose to $5 \mathrm{mg}$ every 8 hours and three discontinued the medication because of adverse events. ${ }^{26}$

Interesting studies in healthy subjects with hyperhidrosis induced by exercise showed no improvement with the use of oxybutynin (different mechanism of sweating?). ${ }^{27,28}$ But in other studies, the drug was effective in reducing perspiration induced by the use of anti-depressives, a frequent adverse event described with the use of these drugs. ${ }^{29,30}$

The second trial with a larger group of patients was conducted in Korea in 21 post-menopausal women with generalized hyperhidrosis. Oxybutynin 5mg was used in 19 women and 10mg daily in two patients, and all of them showed improvement and low adverse events rates. ${ }^{31}$

A randomized study in women with persistent plantar hyperhidrosis after sympathectomy was performed including 16 patients receiving placebo and 16 receiving oxybutynin. An improvement was shown in both the questionnaire of quality of life as well as in the evaluation by Vapometer ${ }^{\circledR}$. The maximum dose used was $10 \mathrm{mg}$ daily. Surprisingly, patients using placebo also improved, but at lower rates than those who took the drug. ${ }^{32}$ In a French trial in which oxybutynin was used for generalized sweating in 30 patients (24 women and six men), starting with a low dose of $1.25 \mathrm{mg}$ and gradually increasing to a maximum dose of $7.5 \mathrm{mg}$, the treatment was considered "very efficient" in $80 \%$ of the patients and "efficient" in $10 \%$. The other three patients discontinued treatment because of complaints of adverse events. ${ }^{33}$ Another Belgian study including nine patients using $7.5 \mathrm{mg}$ of oxybutynin showed improvement in palmar, but not in plantar hyperhidrosis. ${ }^{34}$

Undoubtedly, the group with the highest number of cases and experience is Wolosker et al., who published several papers on the use of oxybutynin in large groups of patients for the treatment of hyperhidrosis in its various locations. ${ }^{35-50}$ Following a standard protocol, they used a dose of $2.5 \mathrm{mg}$ per day in the first week, $5 \mathrm{mg}$ a day divided in two doses from day 8 up to day 42 , and $10 \mathrm{mg}$ daily in two doses from day 43 up to day 84 (12 weeks). The method of assessing the response to treatment was always performed by questionnaires completed by patients. The first study, published in 2011 with 139 patients, showed improvement in palmar hyperhidrosis in more than $80 \%$ individuals and improvement in quality of life in $74.1 \%$. The most frequent adverse event was dry mouth..$^{35}$

In another trial of 19 individuals with facial hyperhidrosis, most of them over 40 years old, the authors reported an overall improvement of $75 \%$, with "great" improvement in $52 \% .{ }^{36}$ In a group with 82 patients with axillary hyperhidrosis, the improvement exceeded $70 \%$, with "great" improvement in $36.3 \%$ and overall improvement in quality of life of $67.5 \% .{ }^{37}$ In 30 patients with plantar hyperhidrosis, $70 \%$ reported an overall improvement, and $66.6 \%$ improved their quality of life. ${ }^{38}$ In 20 patients treated with oxybutynin for hyperhidrosis of unusual sites (back or groin), $80 \%$ experienced improvement of their symptoms, and five patients interrupted treatment because of adverse events. ${ }^{39}$

The same group published a placebo-control randomized study for the treatment of palmar and axillary hyperhidrosis. In 25 patients receiving placebo, $72.7 \%$ had no results after treatment, and in 25 patients receiving oxybutynin $73.9 \%$ refer relief of their symptoms. ${ }^{40}$ When comparing the treatment outcome related to gender, there was no significant difference in improvement, with symptoms relief in about $70 \%$ in both groups. ${ }^{41}$ Nor overweight or obesity was considered limiting factors for treatment, as $67.8 \%$ of patients with overweight and $63 \%$ obese showed significant clinical improvement. ${ }^{42}$ When patients over 40 years were analyzed, 48 subjects between $40-49$ years and 39 patients older than 50 years had significant improvement (75\% in the first group and $87.2 \%$ in the second), with emphasis to the fact that most of the older patients had a high level of improvement. ${ }^{43}$ At the other extreme, 45 children aged 7 to 14 years with palmar hyperhidrosis were evaluated, and over $85 \%$ showed improvement. Regarding the dose, patients with less than $40 \mathrm{~kg}$ were treated with a maximum dose of $5 \mathrm{mg}$ daily, with two daily doses. ${ }^{44}$ In respect to quality of life, improvement after treatment in relation to the pretreatment period was observed in $65.5 \%$ of patients rating "very poor" quality of life, and in 75\% rating "poor" quality of life. ${ }^{45}$

Regarding the treatment of compensatory hyperhidrosis after sympathectomy, in a recent study of 21 patients treated with oxybutynin, $71.4 \%$ reported improvement. Five patients discontinued treatment because of adverse events or lack of response. This study was conducted with a median follow-up of 337 days, longer than previous studies, most with 12 weeks. ${ }^{46}$

Recently, this group has been publishing trials with longer follow-ups. In 397 patients with axillary hyperhidrosis, 114 did not 
CHART 1: Studies with a larger number of patients regarding the dose of oxybutynin, site of hyperhidrosis and results of treatment

\begin{tabular}{|c|c|c|c|c|}
\hline Authors & Number of patients & Dosage & Site & Results \\
\hline Tupker and col. ${ }^{26}$ & 14 & $7,5 \mathrm{mg}$ in $8 ; 15 \mathrm{mg}$ in 3 & Generalized & Improvement in 11 \\
\hline Kim and $\mathrm{col}^{31}$ & $\begin{array}{l}21 \text { (menopausal } \\
\text { women) }\end{array}$ & $5 \mathrm{mg}$ in $19 ; 10 \mathrm{mg}$ in 2 & Generalized & Good results in all \\
\hline Costa Jr and col. ${ }^{32}$ & $\begin{array}{l}16 \text { (and } 16 \text { in the } \\
\text { placebo group) }\end{array}$ & $10 \mathrm{mg}$ & $\begin{array}{l}\text { Hyperhidrosis plantar } \\
\text { after sympatectomy }\end{array}$ & $\begin{array}{l}\text { Good results only in the control } \\
\text { group }\end{array}$ \\
\hline Mailard and col. ${ }^{33}$ & 30 & $7,5 \mathrm{mg}$ & Generalized & Effective in more than $90 \%$ \\
\hline Try and col. ${ }^{34}$ & 9 & $7,5 \mathrm{mg}$ & Palmar Plantar & $\begin{array}{l}\text { Improvement palmar but not in } \\
\text { plantar }\end{array}$ \\
\hline Wolosker and col. ${ }^{35-50}$ & $>570$ & $10 \mathrm{mg}$ & Several & Improvement in all groups \\
\hline
\end{tabular}

\begin{tabular}{|lllll|}
\hline \multicolumn{2}{|c}{ CHART 2: Main contraindications and adverse events with the use of oxybutynin } \\
\hline & $\begin{array}{l}\text { Relative } \\
\text { contraindication }\end{array}$ & $\begin{array}{l}\text { Absolute } \\
\text { contraindication } \\
\text { Ocular }\end{array}$ & $\begin{array}{l}\text { Most frequent side effect- } \\
\text { moderate and severe } \\
(40-70 \% \text { of patients })\end{array}$ & $\begin{array}{l}\text { Less common side effects - usually mild (absent } \\
\text { until at most 10\% of patients })\end{array}$ \\
$\begin{array}{l}\text { Gastrointestinal } \\
\text { Cardiac } \\
\text { Genitourinary }\end{array}$ & $\begin{array}{l}\text { Constipation } \\
\text { Arrhythmias } \\
\text { Urinary retention, }\end{array}$ & $\begin{array}{l}\text { Pregnancy and } \\
\text { lactation }\end{array}$ & Dry mouth & Blurred vision \\
$\begin{array}{l}\text { Central nervous } \\
\text { system }\end{array}$ & $\begin{array}{l}\text { Neuropathy, } \\
\text { Parkinson disease }\end{array}$ & & $\begin{array}{l}\text { Lonstipation } \\
\text { Lipothym, bradycardia tachycardia, palpitations } \\
\text { Urinary retention }\end{array}$ \\
\hline
\end{tabular}

improve and were referred to sympathectomy, eight had intolerable adverse events and 26 preferred surgery instead of medication use for long periods. On a mean follow-up of 17 months, $82.9 \%$ were improved, with better results in women. ${ }^{47}$ The long term results in facial hyperhidrosis in 61 subjects showed maintenance in the improvement level experienced in the first 12 weeks in over $95 \%$ of the patients. ${ }^{48}$ In the palmar hyperhidrosis, two did not improve and were directed to sympathectomy, eight patients had more significant adverse events, 30 did not want to continue using the drug for a long period and 111 did not prolong treatment after six months. Of the 246 patients with over six months of follow-up, $90.2 \%$ presented improvement. ${ }^{49}$ In the plantar hyperhidrosis, out of 39 patients with follow-up longer than six months, all the women showed improvement in $84,7 \%$ of the cases (Chart 1$).^{50}$

In all reviewed papers, the most important adverse event present in approximately $70 \%$ of patients using the drug was dry mouth. Other events are rare and usually mild, but also contribute to the interruption of the medication administration. The main contraindication to the use of oxybutynin is the narrow-angle glaucoma (Chart 2).

\section{CONCLUSIONS}

Oxybutynin presents as an efficient drug with a low level of adverse events for the treatment of primary hyperhidrosis. Main indications for this drug are generalized sweat, multifocal or resistant to other forms of treatment, and as a second or third line treatment for axillary and palmoplantar hyperhidrosis. The doses required for treatment varies among authors, and different dosages may be adapted to the weight of patients and compromised areas, always taking into account the principle of the lowest possible dose to minimize undesirable adverse events (Chart 1). Studies with longer follow-ups are needed to establish the drug's safety and long-term results, although recent studies are encouraging. 


\section{REFERENCES}

1. Maillard H, Lecouflet M. Management of hyperhidrosis. Ann Dermatol Venereol. 2015;142:252-61.

2. Stashak $A B$, Brewer JD. Management of hyperhidrosis. Clin Cosmet Investig Dermatol. 2014;7:285-99.

3. Lakraj AA, Moghimi N, Jabbari B. Hyperhidrosis: anatomy, pathofhysiology and treatment with emphasis on the role of botulinium toxins. Toxins (Basel). 2013:5:821-40.

4. Strutton DR, Kowalski JW, Glaser DA, Stang PE. US prevalence of hyperhidrosis and impact on individuals with axillary hyperhidrosis: Results from a national survey. J Am Acad Dermatol. 2004;51:241-8.

5. Felini R, Demarchi AR, Fistarol ED, Matiello M, Delorenze LM. Prevalence of hyperidrosis in the adult population of Blumenau-SC, Brazil. An Bras Dermatol. 2009;84:361-6

6. Kouris A, Armyra K, Christodoulou C, Karimali P, Karypidis D, Kontochristopoulos G. Quality of life in patients with focal hyperhidrosis before and after treatment with botulinum toxin A. ISRN Dermatol. 2014;2014:30865.

7. Gontijo GT, Gualberto GV, Madureira NAB. Axillary hyperhidrosis treatment update. Surg Cosmet Dermatol. 2011;3:147-51.

8. Stefaniak TJ, Proczko M. Gravimetry in sweating assessment in primary hyperhidrosis and healthy individuals. Clin Auton Res. 2013;23:197-200.

9. Hamm H. Impact of Hyperhidrosis on Quality of life and its Assessment. Dermatol Clin. 2014;32:467-76.

10. de Campos JR, Kauffman P, Werebe Ede C, Andrade Filho LO, Kusniek S, Wolosker $\mathrm{N}$, et al. Questionnaire of quality of life in patients with primary hyperhidrosis. Ann Thorac Surg. 2003;76:886-91.

11. Pariser DM, Ballard A. Topical therapies in hyperhidrosis care. Dermatol Clin. 2014;32:485-90

12. Del Boz J. Systemic treatment of hyperhidrosis. Actas Dermosifiliogr. 2015;106:271-7.

13. Glaser AD. Oral medications. Dermatol Clin. 2014:32:527-32.

14. Andrade PC, Flores GP, Uscello Jde F, Miot HA, Morsoleto MJ. Use of iontofhoresis or phonophoresis for delivering on a botulinum toxin $A$ in the treatment of palmar hyperhidrosis: a report on four cases. An Bras Dermatol. 2011;86:1243-6.

15. Glaser DA, Galperin TA. Managing hyperhidrosis-emerging therapies. Dermato Clin. 2014;32:549-53.

16. Rezende RM, Luz FB. Surgical treatment of axillary hyperhidrosis by suctioncurettage of sweat glands. An Bras Dermatol. 2014;89:940-54.

17. Bejarano B, Manrique M. Simpatectomia torascoscópica: uma revision de la literatura. Neurocirurgia. 2010;21:5-13.

18. Lewitt P. Hyperhidrosis and hypothermia responsive to oxybutynin. Neurology. 1988;38:506-7.

19. Chidedeckel EW. Oxybutynin for diabetic complications. JAMA. 1990;264:2994.

20. van der Linden J, Sinnige HA, van den Dorpel MA. Gustatory sweating and diabetes. Neth J Med. 2000;56:159-62.

21. Shimizu H, Tamada Y, Shimizu J, Ohshima $Y$, Matsumoto $Y$, Sugenoya J. Effectiveness of iontophoresis with alternating current $(A C)$ in the treatment of patients with palmoplantar hyperhidrosis. J Dermatol. 2003:30:444-9.

22. Mijnhout GS, Kloosterman H, Simsek S, Strack van Schijndel RJ, Netelenbos JC Oxybutynin: dry days for patients with hyperhidrosis. Neth J Med. 2006;64:326-8

23. Schollhammer M. Treatment of hyperhidrosis with oxybutynin. Arch Dermatol. 2007;143:544-5

24. Lefrandt JD, Maurer JM. Oxybutynin for hyperhidrosis. Neth J Med. 2007;65:356.

25. Wozniacki L, Zubilewicz T. Primary hyperhidrosis controlled with oxybutynin after unsuccessful surgical treatment. Clin Exp Dermatol. 2009;34:e990-1.

26. Tupker RA, Harmsze AM, Deneer VH. Oxybutynin therapy for generalized hyperhidrosis. Arch Dermatol. 2006;142:1065-6.

27. Harmsze AM, Houte Mv, Deneer VH, Tupker RA. Exercise-induced sweating in healthy subjects as a model to predict a drug's sweat-reducing properties in hyperhidrosis: a prospective, placebo-controlled, double-blind study. Acta Derm Venereol. 2008:88:108-12.

28. van Houte M, Harmsze AM, Deneer VH, Tupker RA. Effect of oxybutynin on exerciseinduced sweating in healthy individuals. J Dermatolog Treat. 2008;19:101-4

29. Grootens KP. Oxybutynin for antidepressant-induced hyperhidrosis. Am J Psychiatry. 2011;168:330-1.

30. Ghaleiha A, Jahangard L, Sherafat Z, Ahmadpanah M, Brand S, Holsboer-Trachsler $\mathrm{E}$, et al. Oxybutynin reduces sweating in depressed patients treated with sertraline: a double-blind, placebo controlled, clinical study. Neuropsychiatr Dis Treat. 2012;8:407-12
31. Kim WO, Kil HK, Yoon KB, Yoo JH. Treatment of generalized hyperhidrosis with oxybutynin in post-menopausal patients. Acta Derm Venereol. 2010;90:291-3.

32. Costa Ada S Jr, Leão LE, Succi JE, Perfeito JA, Filho Castelo A, Rymkiewicz E, et al. Randomized trial-oxybutynin for treatment of persistent plantar hyperhidrosis in women after sympathectomy. Clinics (Sao Paulo). 2014;69:101-5.

33. Maillard $\mathrm{H}$, Fenot $\mathrm{M}$, Bara $\mathrm{C}$, Célérier $\mathrm{P}$. Therapeutic value of moderate -dose oxybutynin in extensive hyperhidrosis. Ann Dermatol Venereol. 2011;138:652-6.

34. Try C, Messikh R, Elkhyat A, Aubin F, Humbert RP. Use of oral oxybutynin at 7,5mg per day in primary hyperhidrosis. Rev Med Liege. 2012;67:520-6.

35. Wolosker N, de Campos JR, Kauffman P, Neves S, Yazbek G, Jatene FB, et al. An alternative to treat palmar hyperhidrosis: use of oxybutynin. Clin Auton Res. 2011;21:389-93.

36. Wolosker N, Campos JR, Kauffman P, Munia MA, Neves S, Jatene FB, et al. The use of oxybutinin for treating facial hyperhidrosis. An Bras Dermatol. 2011:86:451-6.

37. Wolosker N, de Campos JR, Kauffman P, Neves S, Munia MA, BiscegliJatene F et al. The use of oxybutynin for treating axillary hyperhidrosis. Ann Vasc Surg. 2011;25:1057-62

38. Wolosker N, de Campos JR, Kauffman P, Yazbek G, Neves S, Puech-Leao P. Use of oxybutynin for treating plantar hyperhidrosis. Int J Dermatol. 2013;52:620-3.

39. Teivelis MP, Wolosker N, Krutman M, Kauffman P, Campos JR, Puech-Leão P. Treatment of uncommon sites of focal primary hyperhidrosis: experience with pharmacological therapy using oxybutynin. Clinics (Sao Paulo). 2014;69:608-14.

40. Wolosker N, de Campos JR, Kauffman P, Puech-Leão P. A randomized placebo -controlled trial of oxybutynin for the initial treatment of palmar and axillary hyperhidrosis. J Vasc Surg. 2012;55:1696-700.

41. Wolosker N, Krutman M, Campdell TP, Kauffman P, Campos JR, Puech-Leão P. Oxybutynin treatment for hyperhidrosis: a comparative analysis between genders. Einstein (Sao Paulo). 2012;10:405-8.

42. Wolosker N, Krutman M, Kauffman P, Paula RP, Campos JR, Puech-Leão P. Effectiveness of oxybutynin for treatment of hyperhidrosis in overweight and obese patients. Rev Assoc Med Bras (1992). 2013;59:143-7.

43. Wolosker N, Krutman M, Teivelis MP, Paula RP, Kauffman P, Campos JR, et al. Analysis of oxybutynin treatment for hyperhidrosis in patients aged over 40 years. Einstein (Sao Paulo). 2014;12:42-7.

44. Wolosker N, Schvartsman C, Krutman M, Campbell TP, Kauffman P, de Campos $\mathrm{JR}$, et al. Efficacy and quality of life outcomes of oxybutynin for treating palmar hyperhidrosis in children younger than 14 years old. Pediatr Dermatol. 2014;31:48-53.

45. Wolosker N, Krutman M, Teivelis MP, Campbell TP, Kauffman P, de Campos JR, et al. Quality of life before hyperhidrosis treatment as a predictive factor for oxybutynin treatment outcomes in palmar and axillary hyperhidrosis. Ann Vasc Surg. 2014;28:970-6.

46. Teivelis MP, Wolosker N, Krutman M, Milanez de Campos JR, Kauffman P, PuechLeão P. Compensatory hyperhidrosis: results of pharmacologic treatment with oxybutynin. Ann Thorac Surg. 2014;98:1797-802.

47. Wolosker N, Teivelis MP, Krutman M, de Paula RP, Kauffman P, de Campos JR et al. Long -term results of the use of oxybutynin for the treatment of axillary hyperhidrosis. Ann Vasc Surg. 2014;28:1106-12.

48. Wolosker N, Teivelis MP, Krutman M, Campbell TP, Kauffman P, Campos JR et al. Long-term results of the use of oxybutynin for the treatment of facial hyperhidrosis. An Bras Dermatol. 2014;89:912-6.

49. Wolosker N, Teivelis MP, Krutman M, de Paula RP, de Campos JR, Kauffman P, et al. Long term results of oxybutynin treatment for palmar hyperhidrosis. Clin Auton Res. 2014;24:297-303.

50. Wolosker N, Teivelis MP, Krutman M, de Paula RP, Kauffman P, de Campos JR, et al. Long term results of the use of oxybutynin for the treatment of plantar hyperhidrosis. Int J Dermatol. 2015;54:605-11.

How to cite this article: Delort S, Marchi E, Corrêa MA. Oxybutynin as an alternative treatment for hyperhidrosis. An Bras Dermatol. 2017;92(2):217-20. 